\title{
STUDIES ON BIOLUMINESCENCE.
}

\section{Carbon Dioxide Production during Luminescence of CYPRIDINA LUCIFERIN.}

BY E. NEWTON HARVEY.

(From the Physiological Laboratory, Princeton University, Princeton.)

(Received for publication, September 5, 1919.)

All luminous animals require oxygen for luminescence but it is not known whether they give off $\mathrm{CO}_{2}$ as a result of the luminescence. Luminous bacteria produce carbon dioxide but this is no doubt the carbon dioxide of respiration. Even if we could prove that luminous bacteria produced more carbon dioxide than certain non-luminous bacteria, this would not necessarily mean that the excess carbon dioxide was produced during luminescence. Different organisms produce very different quantities of $\mathrm{CO}_{2}$ per body weight and in no necessary relation to luminescence. In 1855, Fabre $^{1}$ published results which indicated that non-luminous portions of a mushroom, Agaricus olearius, produced less $\mathrm{CO}_{2}\left(2.88 \mathrm{cc}\right.$. of $\mathrm{CO}_{2}$ per gm. in 36 hours at $12^{\circ} \mathrm{C}$.) than luminous parts $\left(4.41 \mathrm{cc}\right.$. of $\mathrm{CO}_{2}$ per gm. in 36 hours at $12^{\circ} \mathrm{C}$.). There are, however, many reasons besides luminescence why one part of a plant might produce more $\mathrm{CO}_{2}$ than another.

There are also many facts which indicate that luminescence is in no way connected with the respiration of cells. This is quite obvious in the case of animal cells where respiration is continuous and luminescence appears only as the result of stimulation of the cell. But even in bacteria where respiration and luminescence are both continuous, the two processes are distinct. Some luminous bacteria are facultative anaerobes and will multiply and respire but will not luminesce in the absence of oxygen. ${ }^{2}$ McKenney ${ }^{3}$ found that Bacillus phosphorescens will grow rapidly in 0.5 per cent ether without pro-

${ }^{1}$ Fabre, J. H., Am. Sc. Nat., 1855, iv, 179.

2 Beÿerinck, M. W., Arch. Neer., 1889, xxiii, 416.

3 McKenney, R. E. B., Proc. Biol. Soc. Washington, 1902, xv, 213. 
ducing light. If the temperature of a luminous bacterium is gradually raised, respiration increases continuously up to a relatively high maximum, whereas the luminescence decreases rapidly above a relatively low optimum. The two processes are not equally affected by increasing temperature.

It is obvious that, to measure carbon dioxide production during luminescence, we must use cell-free solutions of the oxidizable material of luminous animals, luciferin, and oxidize it suddenly in order to have the maximum amount of $\mathrm{CO}_{2}$ produced at one time. This experiment can be carried out with the luciferin of Cypridina hilgendorfii, an ostracod crustacean. A brilliant luminescence results from adding a small amount of luciferase solution to a solution of Cypridina luciferin. The preparation of these solutions has been described in a previous paper. ${ }^{4}$

Carbon dioxide production was tested by determining if any change in acidity, which might come from the $\mathrm{CO}_{2}$ produced, occurs when solutions of luciferin and luciferase are mixed. After several attempts to measure acidity by adding an indicator (thymolsulfonephthalein) to the solution, this method was given up because the luciferin and luciferase solutions are yellowish in color, which interferes with the yellow-blue color change of the thymolsulfonephthalein. The electrometric determination with the hydrogen and $0.1 \mathrm{~N} \mathrm{KCl}$ calomel electrode is the most sensitive. A McClendon electrode and Leeds and Northrup potentiometer were used. The acidity of the luciferin solution, luciferase solution, and the two after mixing was found to be the same, $\mathrm{pH}=9.04$. Therefore, not enough $\mathrm{CO}_{2}$ is produced to affect the hydrogen ion concentration.

As both luciferin and luciferase solutions contain proteins and as luciferase is certainly and luciferin probably a protein, it will be seen that their buffer value is relatively high. The luciferin and luciferase solutions, although prepared with distilled water, no doubt contain also a small amount of buffer salts. Our experiments show this much, however, that not enough $\mathrm{CO}_{2}$ is produced during luminescence to saturate the proteins in solution, including luciferin and luciferase themselves. The reaction responsible for luminescence, the oxida-

‘ Harvey, E. N., J. Gen. Physiol., 1918-19, i, 269. 
tion of luciferin, is, therefore, not to be compared to the reactions in cells giving rise to the carbon dioxide of respiration. As I have previously suggested ${ }^{5}$ it is probably of a type similar to the oxidation of a leuco dye to the dye itself. In the case of methylene blue this reaction may be represented as follows:

Leucomethylene blue $\left(\mathrm{C}_{16} \mathrm{H}_{20} \mathrm{~N}_{3} \mathrm{SCl}\right)+\mathrm{O} \leftrightarrows$ methylene blue $\left(\mathrm{C}_{16} \mathrm{H}_{18} \mathrm{~N}_{3} \mathrm{SCl}\right)+\mathrm{H}_{2} \mathrm{O}$

In the case of luciferin we may have

$$
\text { Luciferin }\left(\mathrm{LH}_{2}\right)+\mathrm{O} \leftrightarrows \text { oxyluciferin }(\mathrm{L})+\mathrm{H}_{2} \mathrm{O}
$$

Whether the oxidation of luciferin really proceeds with the formation of $\mathrm{H}_{2} \mathrm{O}$ or whether it involves the actual addition of oxygen, as in the oxidation of hemoglobin, is uncertain. Like methylene blue and oxyhemoglobin the oxyluciferin can be again reduced ${ }^{5}$ but the reduction resembles that of methylene blue in that it will not take place by the mere removal of oxygen, as will the reduction of oxyhemoglobin, but requires also the addition of some reducing agent.

The fact that the reaction luciferin-oxyluciferin is reversible is in itself evidence that no carbon dioxide is produced. Reactions resulting in $\mathrm{CO}_{2}$ production involve considerable energy changes (heat production) and are reversed only with the greatest difficulty and with the addition of a large amount of energy. Whether any considerable amount of heat is produced during oxidation of luciferin will be discussed in the following paper.

${ }^{5}$ Harvey, E. N., J. Gen. Physiol., 1918-19, i, 133. 